\title{
Gravitacijski separatori plin/kapljevina. Dio I.
}

DOI: 10.15255/KUI.2015.002

KUI-14/2016

Stručni rad

Prispjelo 5. siječnja 2015.

Prihvaćeno 7. prosinca 2015.

\section{E. Beer*}

Aleja Blaža Jurišića 9, 10000 Zagreb

\| Sažetak

Gravitacijski separatori plin/kapljevina česte su procesne jedinice u pridobivanju i preradi nafte i plina, petrokemijskoj i kemijskoj procesnoj industriji. Kako su jednostavni po konstrukciji, često se smatra da su i jednostavni za dimenzioniranje. lako postupak dimenzioniranja nije složen kao npr. dimenzioniranje destilacijske kolone, nije ni jednostavan, posebno ako su u pitanju trofazni separatori. $U$ ovoj seriji dan je prikaz temeljnih osnova proračuna, tipova separatora i postupaka dimenzioniranja.

Prvi dio je prikaz teorijskih osnova separacije, dijelova separatora i tipova s njihovim međusobnim prednostima i nedostatcima.

\| Ključne riječi

Gravitacijski separatori, separatori para/kapljevina, separatori para/kapljevina/kapljevina,

raspodjelnici pojenja, odvajači kapljica

\section{Uvod}

Separatori ili odvajači plin/kapljevina česte su procesne jedinice u postrojenjima procesne kemijske industrije $\mathrm{i}$ prerade nafte a u pridobivanju nafte i plina su nezamjenjivi dio procesa. Mnogo je napisano o dimenzioniranju i projektiranju separatora a isto tako je mnogo informacija i uputa od projektnih organizacija. Teorijske osnove i temeljne korelacije o procesu odvajanja su dobro poznate, međutim, činjenica je da se dimenzioniranje velikim dijelom temelji na iskustvenim podatcima koji dosta variraju od autora do autora i izbor relevantnih podataka za dimenzioniranje je subjektivna odluka. Također, iako je relativno mnogo iskustvenih podataka i preporuka za izbor parametara i dimenzioniranje dvofaznih separatora, relativno je malo podataka za dimenzioniranje trofaznih separatora i najvećim dijelom su to podatci projektnih organizacija.

U ovoj seriji članaka dan je pregled postupaka i preporuka za proračun gravitacijskih separatora bez ugrađenog uređaja za dodatno odvajanje kapljica tekućine i s ugrađenim uređajem, odvajačima kapljica.

\section{Teorijske osnove}

\section{Odvajanje gravitacijom}

U dvofaznoj smjesi čestice dispergirane faze izdvajat će se iz kontinuiranog fluida ako je gravitacijska sila koja djeluje na česticu veća od sile trenja između kontinuirane faze i čestice dispergirane faze. To će izdvajanje biti ubrzano gibanje sve dok se te dvije sile ne izjednače. Od tog momenta brzina izdvajanja čestice bit će konstantna. Te se sile mogu matematički opisati.

Sila gravitacije:

$$
F_{\mathrm{g}}=\frac{M_{\mathrm{p}}\left(\rho_{\mathrm{p}}-\rho\right) g}{\rho_{\mathrm{p}}}
$$

Sila trenja:

$$
F_{\mathrm{D}}=\frac{\pi}{8} C_{\mathrm{D}} D_{\mathrm{p}}^{2} u^{2} \rho
$$

Izjednačavanjem ovih dviju jednadžbi dobivamo jednadžbu za brzinu kontinuirane faze kod koje se čestica dispergirane faze izdvaja konstantnom, graničnom brzinom $u_{\mathrm{t}}$ :

$$
u_{\mathrm{t}}=\sqrt{\frac{4 g D_{\mathrm{p}}\left(\rho_{\mathrm{p}}-\rho\right)}{3 \rho C_{\mathrm{D}}}}
$$

Koeficijent otpora, $C_{D}$, funkcija je oblika čestice i Reynoldsove značajke i ovisi o obliku čestice (slika 1).

Za čestice oblika sfere Reynoldsova značajka je definirana s:

$$
\operatorname{Re}_{\mathrm{p}}=\frac{D_{\mathrm{p}} u \rho}{\mu}
$$

\footnotetext{
*Eduard Beer

e-pošta: eduard.beer@inet.hr
} 


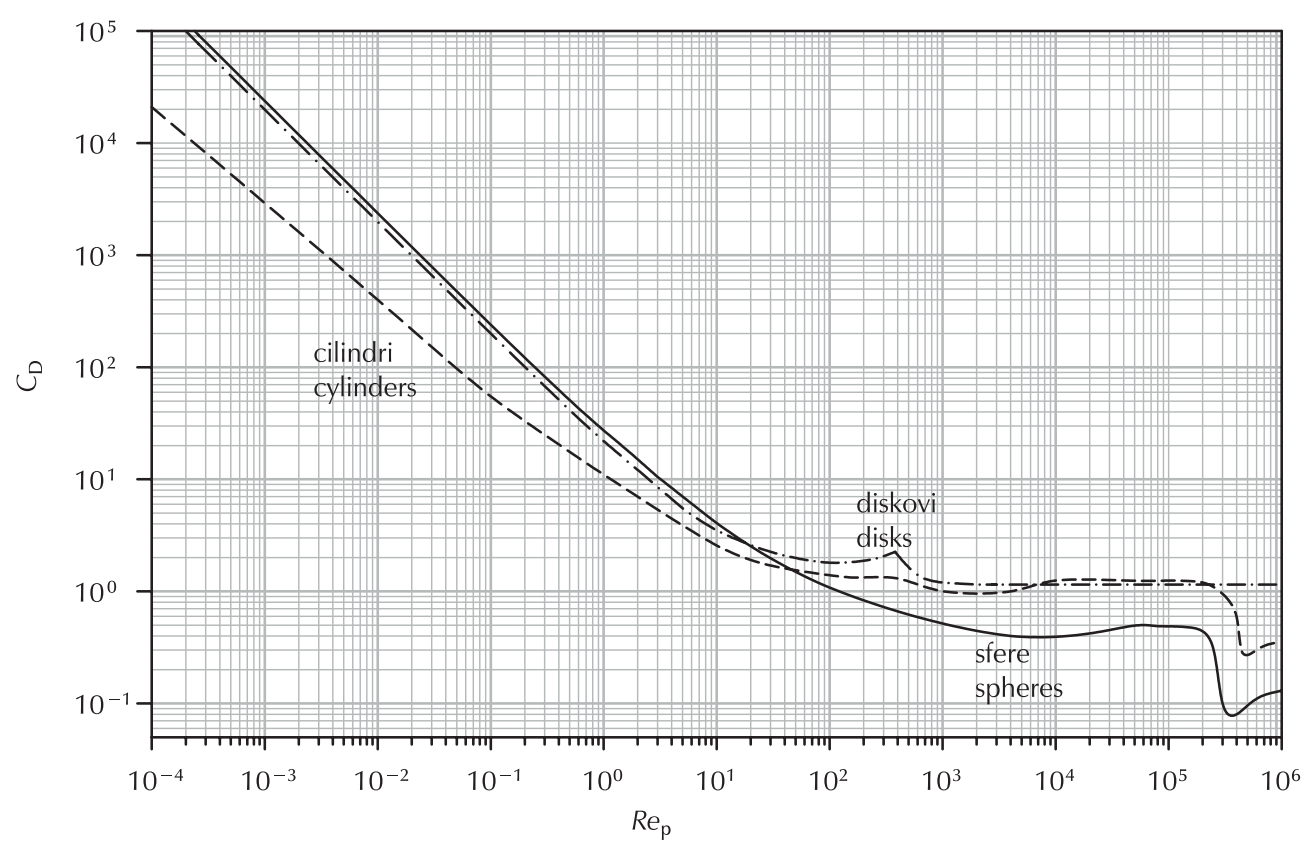

Slika 1 - Koeficijent otpora ${ }^{1}$ za sfere, diskove i cilindre

Fig. 1 - Drag coefficient ${ }^{1}$ for spheres, disks and cylinders

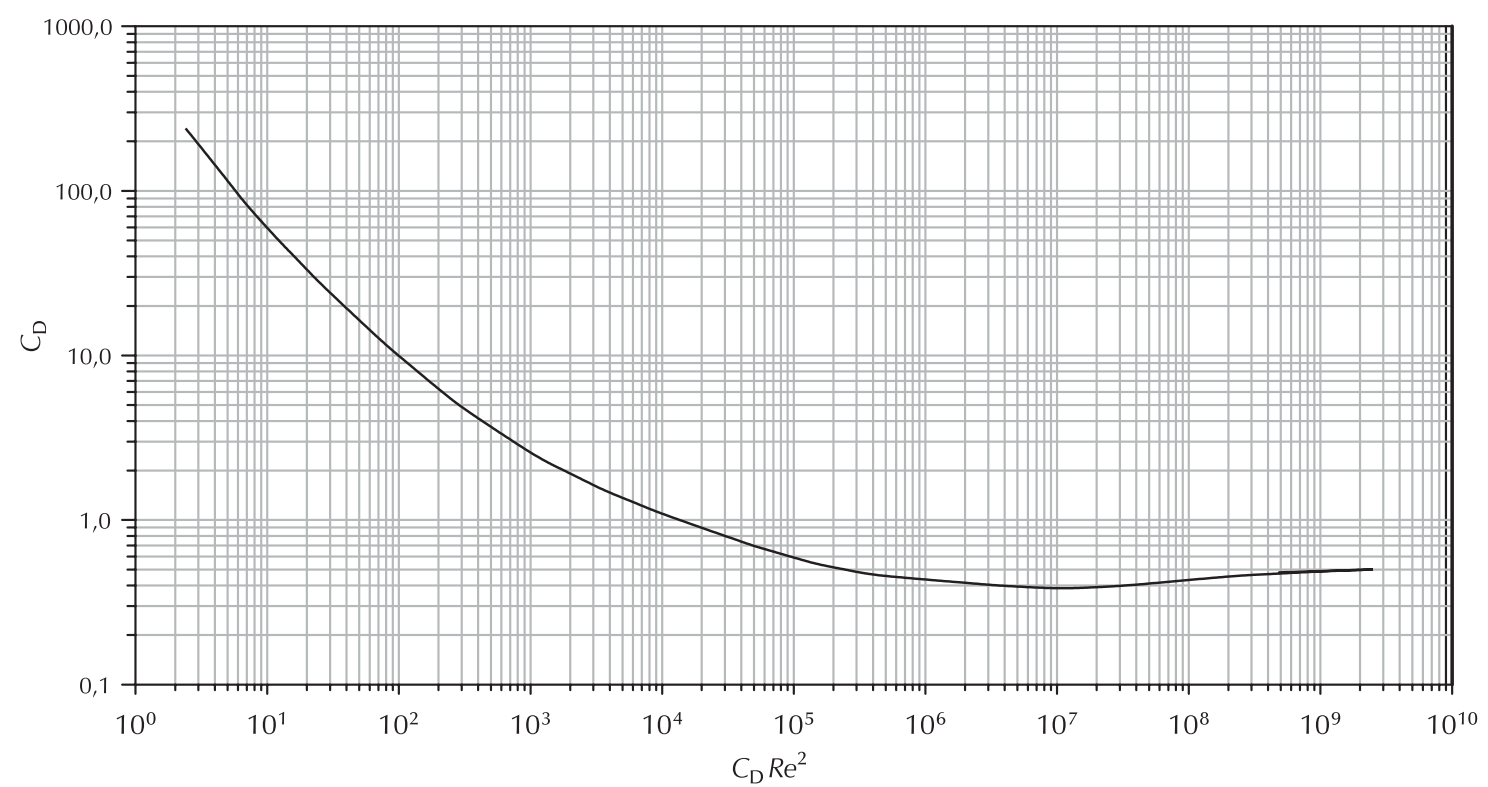

Slika 2 - Koeficijent otpora ${ }^{2}$ kao funkcija umnoška $C_{D} R^{2}$

Fig. 2 - Drag coefficient ${ }^{2}$ as a function of $C_{D} R^{2}$

Kod malih vrijednosti za $R e, 0,01<\operatorname{Re}_{\mathrm{p}} \leq 1,0$, u području valjanosti Stokesova zakona:

$$
C_{D}=\frac{24}{R e_{p}}
$$

U prijelaznom području, $0,1<\operatorname{Re}_{\mathrm{p}}<1000$ :

$$
C_{\mathrm{D}}=\left(\frac{24}{R e_{\mathrm{p}}}\right)\left(1+0,14 \cdot \operatorname{Re}_{\mathrm{p}}^{0,7}\right)
$$

Točnost procjene je $\pm 6 \%$.
$U$ području gdje je primjenjiva Newtonova zakonitost, $1000<\operatorname{Re}_{\mathrm{p}}<350000$ :

$$
C_{D}=0,445
$$

s točnosti od $\pm 13 \%$.

U tom obliku proračun granične brzine plina je moguć samo iterativno jer su promjer kapljice, $D_{\mathrm{p}}$, i granična brzina, $u_{\mathrm{t}}$ u izrazima za brzinu i Reynoldsovu značajku. NajČešći način računanja $C_{D}$ je $s$ pomoću grafa na slici 2 gdje je $C_{D}$ dan kao funkcija umnoška $C_{D} R e^{2}$. 
Umnožak $C_{D} R^{2}$ izračuna se iz:

$$
C_{\mathrm{D}} \operatorname{Re}^{2}=\frac{4 g \rho_{\mathrm{G}} D_{\mathrm{p}}^{3}\left(\rho_{\mathrm{L}}-\rho_{\mathrm{C}}\right)}{3 \mu_{\mathrm{G}}^{2}}
$$

Granična brzina može se izračunati i s pomoću Stokesove i Newtonove korelacije.

$U$ području malih vrijednosti Reynoldove značajke, $0,01<R e \leq 1,0$, brzina izdvajanje čestica (sfere) može se izračunati i iz Stokesove zakonitosti:

$$
u_{\mathrm{t}}=g D_{\mathrm{p}}^{2} \frac{\rho_{\mathrm{p}}-\rho}{18 \mu}
$$

Kod vrijednosti Reynoldsove značajke iznad 1000 (Re $>1000)$ za brzinu izdvajanja vrijedi Newtonova zakonitost:

$$
u_{\mathrm{t}}=\left(3 g D_{\mathrm{p}} \frac{\rho_{\mathrm{p}}-\rho}{\rho}\right)^{1 / 2}
$$

U prijelaznom području, $1<\operatorname{Re} \leq 1000$, brzina izdvajanja se izračuna iz:

$$
u_{\mathrm{t}}=0,153 g^{0,71} D_{\mathrm{p}}^{1,143} \frac{\left(\rho_{\mathrm{p}}-\rho\right)^{0,714}}{\rho^{0,286} \mu^{0,429}}
$$

Za primjenu gornjih korelacija potrebno je znati korektni režim strujanja $(R e)$ da bi se izračunala granična brzina, što baš i nije jednostavno odrediti. Jednostavan postupak uz primjenu samo podataka o fizičkim svojstvima dali su McCabe i Smith. ${ }^{3}$ Definirali su kriterij režima strujanja:

$$
K_{\mathrm{rs}}=D_{\mathrm{p}}\left[\frac{g \rho\left(\rho_{\mathrm{p}}-\rho\right)}{\mu^{2}}\right]^{1 / 3}
$$

Ako je $K_{\mathrm{rs}}<3,3$, tada je to područje Stokesove zakonitosti. Ako je 3,3 $\leq K_{\mathrm{rs}} \leq 53,6$, tada je to prijelazno područje. Za $K_{\mathrm{rs}}>43,6$ vrijedi Newtonov zakon.

Granična brzina se izračuna iz:

$$
u_{\mathrm{t}}=\left[\frac{4 g D_{\mathrm{p}}^{1+n}\left(\rho_{\mathrm{p}}-\rho\right)}{3 b \mu^{n} \rho^{1-n}}\right]^{1 /(2-n)}
$$

gdje konstante $b$ i $n$ ovise o $K_{\mathrm{rs}}$ i dane su u tablici 1 .

Tablica 1 - Kriterij režima strujanja te konstante $b$ i $n$ u jedn. (13) Table 1 - Flow patern criterion and constants $b$ and $n$ in Eq. (13)

\begin{tabular}{l|c|c|c}
\hline $\begin{array}{l}\text { Zakonitost } \\
\text { Settling law }\end{array}$ & $K_{\mathrm{rs}}$ & $b$ & $n$ \\
\hline $\begin{array}{l}\text { Stokesov zakon } \\
\text { Stokes' law } \\
\text { prijelazno područje } \\
\text { transition area }\end{array}$ & $K_{\mathrm{rs}}<3,3$ & 24,0 & 1,0 \\
$\begin{array}{l}\text { Newtonov zakon } \\
\text { Newton's law }\end{array}$ & $K_{\mathrm{rs}}>43,6$ & 0,44 & 0 \\
\hline
\end{tabular}

Ako vrijednost $K_{\text {rs }}$ prelazi 2360 , tada treba biti oprezan i ne treba vjerovati rezultatu za $u_{\mathrm{t}}$ jer $\mathrm{u}$ tom području dolazi do naglih promjena $C_{D} s$ malim promjenama brzine strujanja. Jednadžba za graničnu brzinu plina (3) obično se piše u obliku poznatom kao Souders-Brownova korelacija:

$$
u_{\mathrm{t}}=K \sqrt{\frac{\left(\rho_{\mathrm{p}}-\rho\right)}{\rho}}
$$

gdje je $K$ (Souders-Brownov koeficijent, $K$-faktor, faktor brzine para)

$$
K=\sqrt{\frac{4 g D_{\mathrm{p}}}{3 C_{\mathrm{D}}}}
$$

Souders-Brownov koeficijent može se izračunati bez poznavanja koeficijenta otpora, $C_{\mathrm{D}}, \mathrm{iz}^{4}$

$$
\begin{gathered}
\text { za } \operatorname{Re}_{\mathrm{p}} \leq 1: K=0,0556 g D_{p}^{2}\left[\rho\left(\rho_{\mathrm{p}}-\rho\right)\right]^{1 / 2} \\
\text { za } \operatorname{Re}_{\mathrm{p}}=1: K=0,236\left(g D_{\mathrm{p}}\right)^{1 / 2} \\
\text { za } 1<\operatorname{Re}_{\mathrm{p}} \leq 1000: \\
K=0,153 g^{0,71} D_{p}^{1,143}\left[\frac{\rho\left(\rho_{\mathrm{L}}-\rho\right)}{\mu^{2}}\right]^{0,214}
\end{gathered}
$$

Iz korelacija je vidljivo da Souders-Brownov koeficijent ovisi o svojstvima faza a posebno, ako se radi o dvofaznom sustavu plin/kapljevina, o radnom tlaku. Ilustracija te ovisnosti za sustav zrak/voda dana je na slici 3.

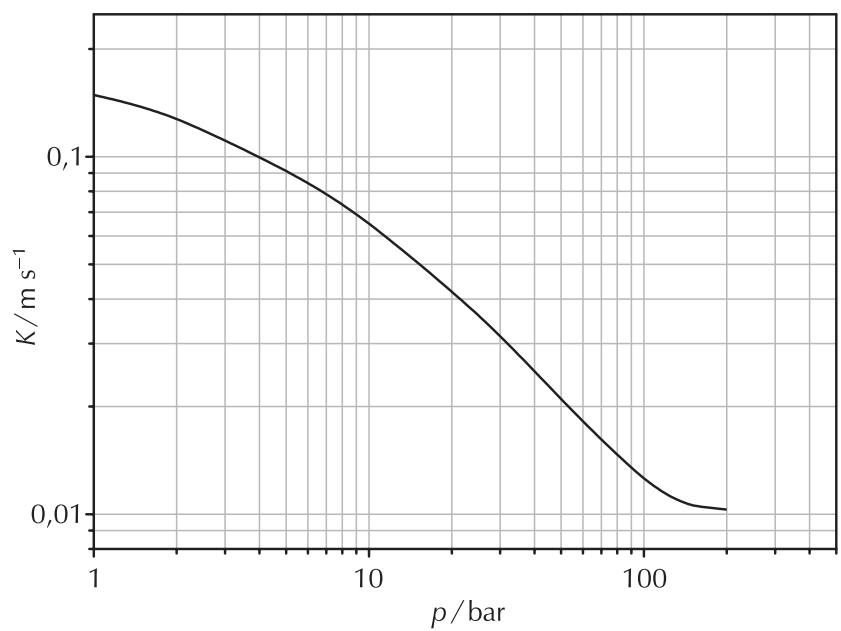

Slika 3 - Ovisnost Souders-Brownova koeficijenta o radnom tlaku smjese zraka i vode $\left(25^{\circ} \mathrm{C}, D_{\mathrm{p}}=100 \mathrm{~mm}\right)$

Fig. 3 - Souders-Brown coefficient as a function of operating pressure of air-water mixture $\left(25^{\circ} \mathrm{C}, D_{\mathrm{p}}=100 \mathrm{~mm}\right)$

Ako se radi o smjesi plina i kapljevine, tada je plin praktično bez iznimaka kontinuirana a tekućina dispergirana faza. 
Međutim, ako se radi o sustavu dvije nemješljive kapljevine, ovisno o radnim uvjetima i fizičkim svojstvima kapljevina, kontinuirana faza može biti ili lakša ili teža kapljevina. Kako su granične brzine odvajanja kapljica lakše kapljevine iz teže ili teže iz lakše različite, to je važno znati koja je kapljevina kontinuirana, a koja dispergirana faza. Za to može poslužiti kriterij Selkera i Sleichera. ${ }^{5}$ Kriterij je faktor disperzije:

$$
\Theta=\frac{Q_{\mathrm{v}, \mathrm{LI}}}{Q_{\mathrm{v}, \mathrm{Lh}}}\left(\frac{\rho_{\mathrm{LI}} \mu_{\mathrm{Lh}}}{\rho_{\mathrm{Lh}} \mu_{\mathrm{Ll}}}\right)
$$

a rezultati su:

$\Theta<0,3$ : $\quad$ lakša kapljevina je uvijek dispergirana

$0,3<\Theta<0,5$ : lakša kapljevina je vjerojatno dispergirana

$0,5<\Theta<2,0$ : vjerojatna inverzija faza

2,0 $<\Theta<3,3$ : teža kapljevina je vjerojatno dispergirana

$\Theta>3,3: \quad$ dispergirana je teža kapljevina

(vidjeti citirani članak za kritično dimenzioniranje).

\section{Odvajanje kolizijom}

Odvajanje gravitacijom može biti djelotvorno samo ako se osigura dovoljno dugo vrijeme odvajanja u separatoru, a to znači i separatore velikih dimenzija. U okviru prihvatljivih dimenzija djelotvornost odvajanja dispergiranih čestica veličine 200 do $250 \mathrm{~mm}$ je oko 90 \%. To može zadovoljiti u nekim procesima, ali ako se traži djelotvornije odvajanje, tada se moraju ugraditi u separator odvajači kapljica.

Tri su najčešće upotrebljavana tipa odvajača: žičane mrežice, pločasti odvajači i sloj vlakana. Izbor ovisi o zahtjevima procesa.

U sva tri tipa osnovni su mehanizmi koalescencija uslijed inercijske kolizije, izravne kolizije i difuzije (slika 4).

Inercijska kolizija. Radi dovoljno velike mase kapljice u struji plina imaju dovoljnu količinu gibanja da se izdvoje iz promijenjenog smjera toka plina i nastave se pravocrtno gibati dok se ne sudare s površinom odvajača. Udarom u površinu adhezijom nastaje film tekućine čija debljina sloja raste dok ne dođe do stvaranja kapljica većih promjera koje se izdvajaju gravitacijski.

Izravna kolizija. Čestice čiji je promjer manji nemaju dovoljnu količinu gibanja da se izdvoje iz toka plinske struje pri promjeni smjera. Među tim česticama ima ih koje su dovoljno blizu površini odvajača, razmak između osi čestice i površine odvajača manji je od $1 / 2 D_{p}$, čestice dodiruju površinu odvajača i zadržavaju se na njoj stvarajući film tekućine kao i u slučaju inercijske kolizije.

Difuzija. Još manje čestice, promjer manji od 1,0 mm, podložne su Brownovu gibanju uslijed sudara s molekulama plina. To nasumično gibanje uzrokuje da se čestice sudaraju s površinom odvajača i zadrže na površini.

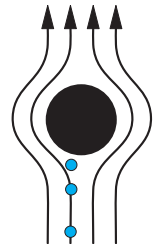

inercijska kolizija

inertial impaction

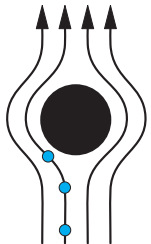

izravna kolizija direct

interception

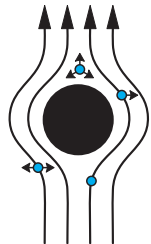

Brownovo gibanje

Brownian capture

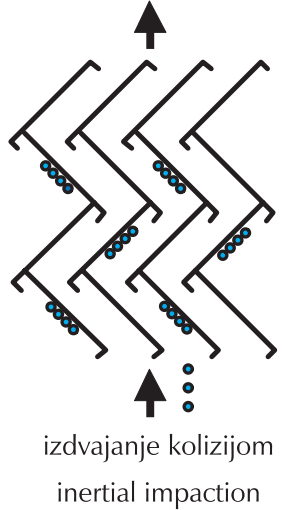

Slika 4 - Mehanizmi izdvajanja čestica tekućine iz struje plina Fig. 4 -Mechanisms of liquid particles separation from gas flow

\section{Tipovi separatora}

Dva su osnovna tipa separatora bez obzira radilo se o dvofaznim ili trofaznim separatorima: okomiti i vodoravni. Njihova svojstva ih čine prikladnim za određenu namjenu. Usporedba svojstava dana je u tablici 2.

Dok kod dvofaznih separatora (plin/kapljevina) nema varijacija u izvedbi, kod trofaznih (plin/kapljevina/kapljevina) ima više tipova po izvedbi, posebno kod vodoravnih. O njihovim specifičnostima bit će govora kasnije. Također svi tipovi mogu biti izvedbe s odvajačem kapljica ili bez njega, ovisno o zahtjevima procesa nakon separatora.

\section{Unutarnji dijelovi}

Dva su uređaja koji se ugrađuju unutar separatora: raspodjelnik ulazne smjese i odvajač kapljica. I dok se odvajač kapljica ne mora uvijek ugraditi, raspodjelnik ulazne smjese je obvezatni dio separatora.

\section{Raspodjelnik ulazne smjese - distributor}

Distributori imaju sljedeću namjenu:

- primarno odvajanje plina i kapljevine. Bilo kakvo odvajanje na ulazu u separator rasteretit će preostale dijelove separatora i omogućiti djelotvornije odvajanje;

- osigurati dobru raspodjelu plina i kapljevine (kapljevina);

- smanjiti na najmanju mjeru odnošenje kapljevine s plinom uslijed razbijanja kapljevine u sitne kapljice ako ulazni tok velikom brzinom udara u površinu kapljevine u separatoru;

- ako je pojna smjesa podložna pjenjenju ulaznu, uređaj bi trebao spriječiti ili smanjiti pjenjenje.

Ima ih više tipova, deflektori, koljena $90^{\circ}$, poluotvorene cijevi, T-raspodjelnika pa do raspodjelnika s krilcima (slike 5-8). 
Tablica 2 - Usporedba svojstava okomitih i vodoravnih separatora

Table 2 - Vertical versus horizontal separators - comparison

\begin{tabular}{|c|c|c|}
\hline & $\begin{array}{l}\text { Okomiti } \\
\text { Vertical }\end{array}$ & $\begin{array}{l}\text { Vodoravni } \\
\text { Horizontal }\end{array}$ \\
\hline \multirow{7}{*}{$\begin{array}{l}\text { prednosti } \\
\text { advantages }\end{array}$} & $\begin{array}{l}\text { lakši za čišćenje } \\
\text { easier cleaning }\end{array}$ & \multirow{3}{*}{$\begin{array}{c}\text { može procesuirati puno veće omjere plin/ } \\
\text { kapljevina, jer izvedba omogućuje puno veće } \\
\text { brzine plina } \\
\text { possible processing of higher gas/liquid ratio due } \\
\text { to much higher gas velocities }\end{array}$} \\
\hline & $\begin{array}{l}\text { zauzima manju površinu } \\
\text { less area for installation }\end{array}$ & \\
\hline & $\begin{array}{c}\text { osigurava bolju kontrolu pri poremećaju } \\
\text { better up-set control }\end{array}$ & \\
\hline & $\begin{array}{l}\text { regulacija razina nije kritična } \\
\text { level control not critical }\end{array}$ & $\begin{array}{l}\text { jeftiniji od okomitog separatora } \\
\text { cheaper than vertical }\end{array}$ \\
\hline & \multirow{3}{*}{$\begin{array}{c}\text { manja tendencija odnošenja kapljevine zbog većeg } \\
\text { okomitog razmaka između razine kapljevine i izlaza plina } \\
\text { less droplet entrainment due to higher vertical distance } \\
\text { between liquid level and gas outlet }\end{array}$} & $\begin{array}{c}\text { zahtijeva manje cjevovoda za povezivanje } \\
\text { less interconnecting pipes }\end{array}$ \\
\hline & & $\begin{array}{l}\text { smanjuje turbulenciju i pjenjenje } \\
\text { lower turbulence and foaming }\end{array}$ \\
\hline & & $\begin{array}{c}\text { nekoliko separatora se mogu okomito povezati pa } \\
\text { time smanjiti potrebna površina } \\
\text { several separators could be vertically connected } \\
\text { reducing area for installation }\end{array}$ \\
\hline \multirow{4}{*}{$\begin{array}{l}\text { nedostatci } \\
\text { drawbacks }\end{array}$} & \multirow{2}{*}{$\begin{array}{c}\text { za isti kapacitet protoka plina ima veći promjer od } \\
\text { vodoravnog } \\
\text { for equal gas flow larger diameter than horizontal }\end{array}$} & $\begin{array}{l}\text { u pravilu zahtijeva veću površinu } \\
\text { larger installation area }\end{array}$ \\
\hline & & $\begin{array}{l}\text { regulacija razine je kritičnija } \\
\text { more critical liquid level control }\end{array}$ \\
\hline & \multirow{2}{*}{$\begin{array}{l}\text { skuplji za izvedbu } \\
\text { more expensive }\end{array}$} & $\begin{array}{l}\text { obujam za poremećaje je ponekad ograničen } \\
\text { surge volume is sometimes limited }\end{array}$ \\
\hline & & $\begin{array}{l}\text { puno teže se čisti } \\
\text { more difficult to clean }\end{array}$ \\
\hline $\begin{array}{l}\text { najčešća upotreba } \\
\text { typical use }\end{array}$ & $\begin{array}{l}\text { mali ili srednji omjer plin/kapljevina i kada se očekuju } \\
\text { relativno velik povremeni porasti protoka kapljevine } \\
\text { low and medium gas/liquid ratio, when temporary } \\
\text { relatively high liquid flow is expected }\end{array}$ & $\begin{array}{l}\text { velik omjer plin/kapljevina, odvajanje dviju } \\
\text { kapljevina; prikladan za različite situacije u } \\
\text { procesu. } \\
\text { high gas/liquid ratio, adequate for different } \\
\text { process situations }\end{array}$ \\
\hline
\end{tabular}

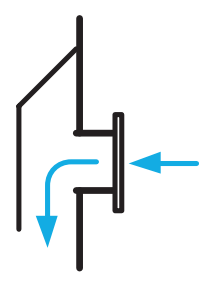

a)
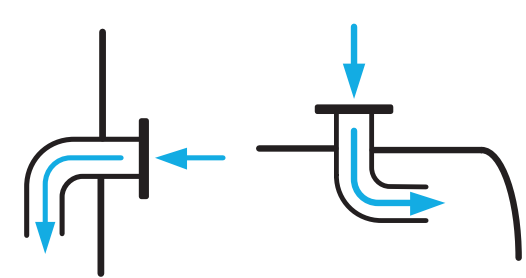

b)

Slika 5 - Deflektor (a) i koljena $90^{\circ}$ (b)

Fig. 5 - Inlet devices: deflector (a), knee (b)
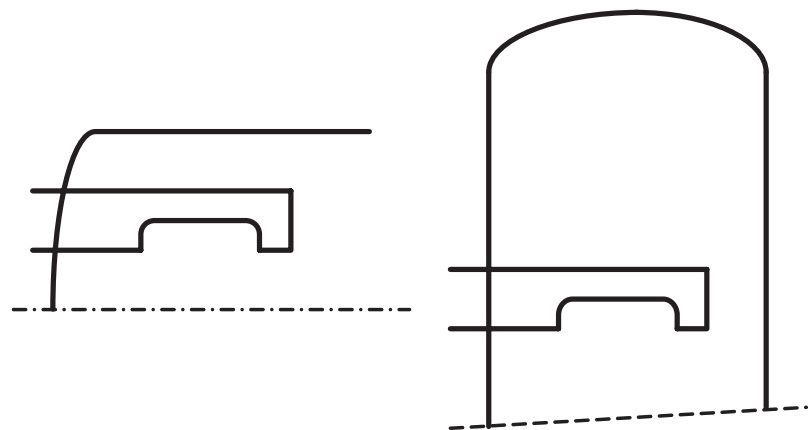

Slika 6 - Polucijev

Fig. 6 - Half-pipe feed distributor 


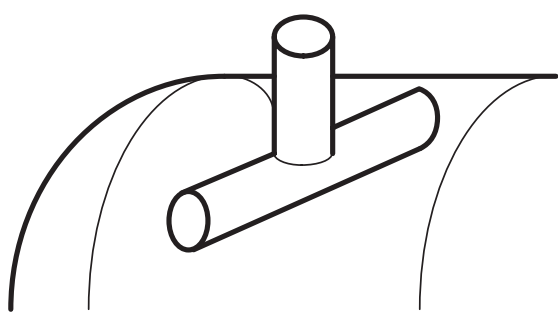

Slika 7 - T-raspodjelnik

Fig. 7 - T-pipe feed distributor

Svaki tip raspodjelnika ima svoje karakteristike na temelju kojih se načini izbor.

Deflektor (slika 5 (a)). To je bio najčešće upotrebljavan tip raspodjelnika prije nego su uvedeni raspodjelnici s većom djelotvornosti odvajanja. Radi slično koljenu, tj. naglo mijenja smjer toka i brzinu pojne smjese i time potpomaže primarno razdvajanje faza.

Koljeno $90^{\circ}$ (slika 5 (b)). Upotrebljava se u vodoravnim separatorima za usmjeravanje ulaznog toka prema podnici. Normalno se upotrebljavaju koljena s dugačkim polumjerom. Koljena s kratkim polumjerom upotrebljavaju se samo ako je visina parnog prostora iznad razine kapljevine nedovoljna za ugradnju koljena s dugim polumjerom.

Poluotvorena cijev (slika 6). To je zapravo modifikacija koljena prikladna za instalaciju u okomitim i vodoravnim separatorima. Način instaliranja prikazan je na slici 6 .

T-raspodjelnik (slika 7). Distributor T oblika s otvorima (kružni ili okomiti prorezi) na vodoravnom dijelu usmjerenom prema podnici (vodoravni separator) ili stijenkama separatora (okomiti separator).

Raspodjelnik s krilcima (slika 8). Najjednostavniji tip je uređaj s dva krilca (rašljasti, bifurkator). Raspodjelnik s više
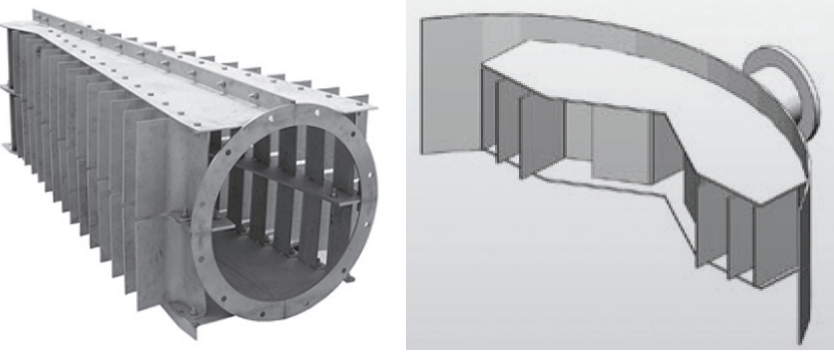

Slika 8 - Raspodjelnici s krilcima

Fig. 8 - Vane (schoepentoeter) feed distributor

krilaca prvi je uveo Shell ${ }^{6}$ prije petnaestak godina i nazvao ga schoepentoeter distributor. Kasnije su taj tip distributora drugi proizvođači nazvali multi vane distributor tako da se u literaturi susreću oba naziva. Daje zadovoljavajuću raspodjelu toka s malim padom tlaka. U vodoravnim separatorima prikladan je samo za ulaz s vrha separatora. Plinska faza dobro se odvaja od tekuće i raspoređuje duž posude, dok je brzina tekuće faze bitno smanjena i usmjerena prema stijenkama posude. Kod pojenja s relativno velikim protokom plina u odnosu na tekućinu osigurava vrlo dobru raspodjelu plina, što omogućava manju visinu između raspodjelnika i površine tekućine.

Pregled svojstava dan je u tablicama 3 i 4.

Tablica 3 - Djelotvornost odvajanja tekućine od plina različitih raspodjelnika ${ }^{7}$

Table 3 - Separation efficiency for different feed distributors ${ }^{7}$

\begin{tabular}{l|c|c|c|c}
\hline $\begin{array}{l}\text { Raspodjelnik } \\
\text { Distributor }\end{array}$ & $\begin{array}{c}\text { Bez } \\
\text { raspodjelnika } \\
\text { No } \\
\text { distributor }\end{array}$ & $\begin{array}{c}\text { Deflektor } \\
\text { Deflector }\end{array}$ & $\begin{array}{c}\text { Polucijev } \\
\text { Halfpipe }\end{array}$ & $\begin{array}{c}\text { S krilcima } \\
\text { Vane } \\
\text { distributor }\end{array}$ \\
\hline $\begin{array}{l}\text { djelotvornost } \\
\text { efficiency }\end{array}$ & $<0,5$ & 0,5 & 0,8 & $>0,95$ \\
\hline
\end{tabular}

Tablica 4 - Usporedba svojstava različitih tipova ulaznih raspodjelnika ${ }^{8}$

Table 4 - Performances of different types of feed distributors ${ }^{8}$

\begin{tabular}{|c|c|c|c|c|}
\hline $\begin{array}{l}\text { Svojstvo } \\
\text { Performance }\end{array}$ & $\begin{array}{l}\text { Bez ulaznog } \\
\text { distributora } \\
\text { No inlet device }\end{array}$ & $\begin{array}{l}\text { Deflektor } \\
\text { Deflector baffle }\end{array}$ & $\begin{array}{l}\text { Poluotvorena } \\
\text { cijev } \\
\text { Half open pipe }\end{array}$ & $\begin{array}{l}\text { Raspodjelnik s krilcima } \\
\text { Vane type distributor }\end{array}$ \\
\hline $\begin{array}{l}\text { odvajanje kapljevine } \\
\text { bulk liquid separation }\end{array}$ & $\begin{array}{l}\text { loše } \\
\text { poor }\end{array}$ & $\begin{array}{l}\text { loše } \\
\text { poor }\end{array}$ & $\begin{array}{l}\text { prosječno } \\
\text { average }\end{array}$ & $\begin{array}{l}\text { dobro } \\
\text { good }\end{array}$ \\
\hline $\begin{array}{l}\text { raspodjela plina i kapljevine } \\
\text { gas/liquid distribution }\end{array}$ & $\begin{array}{l}\text { loše } \\
\text { poor }\end{array}$ & $\begin{array}{l}\text { loše } \\
\text { poor }\end{array}$ & $\begin{array}{l}\text { prosječno } \\
\text { average }\end{array}$ & $\begin{array}{l}\text { dobro } \\
\text { good }\end{array}$ \\
\hline $\begin{array}{l}\text { sprječavanje odnošenja kapljevine s međufazne } \\
\text { površine plin/kapljevina } \\
\text { liquid re-entrainment from gas/liquid interface }\end{array}$ & $\begin{array}{l}\text { vrlo loše } \\
\text { very poor }\end{array}$ & $\begin{array}{l}\text { vrlo loše } \\
\text { very poor }\end{array}$ & $\begin{array}{l}\text { loše } \\
\text { poor }\end{array}$ & $\begin{array}{l}\text { dobro } \\
\text { good }\end{array}$ \\
\hline $\begin{array}{l}\text { minimalno razbijanje kapljica tekućine } \\
\text { minimize droplet shater }\end{array}$ & $\begin{array}{l}\text { loše } \\
\text { poor }\end{array}$ & $\begin{array}{l}\text { vrlo loše } \\
\text { very poor }\end{array}$ & $\begin{array}{l}\text { prosječno } \\
\text { average }\end{array}$ & $\begin{array}{l}\text { vrlo dobro } \\
\text { very good }\end{array}$ \\
\hline $\begin{array}{l}\text { sprječavanje pjenjenja } \\
\text { foaming prevention }\end{array}$ & $\begin{array}{l}\text { vrlo loše } \\
\text { very poor }\end{array}$ & $\begin{array}{l}\text { vrlo loše } \\
\text { very poor }\end{array}$ & $\begin{array}{l}\text { loše } \\
\text { poor }\end{array}$ & $\begin{array}{l}\text { prosječno } \\
\text { average }\end{array}$ \\
\hline
\end{tabular}


Iz tablice bi se moglo zaključiti da uvijek treba birati najsofisticiraniji ulazni raspodjelnik. Treba reći da je usporedba u tablici dana za separatore jednakih dimenzija, za jednake radne uvjete (temperatura, tlak, protoci) samo su ugrađeni različiti raspodjelnici. Odnošenje kapljica kapljevine s međufazne površine, ako je raspodjelnik po visini jednako udaljen od površine kapljevine, kod poluotvorene cijevi je veće u odnosu na raspodjelnik s krilcima, ali ako se osigura dovoljna udaljenost od poluotvorene cijevi i površine kapljevine, to se svojstvo može bitno poboljšati. Drugim riječima loše svojstvo raspodjelnika može se poboljšati dobrim dimenzioniranjem separatora. Također treba reći da su svojstva u tablici svojstva korektno dimenzioniranih uređaja. Loše dimenzioniran uređaj može imati lošije svojstvo nego je navedeno u tablici.

Promjer ulazne cijevi također varira prema tipu raspodjelnika. Raspodjelnici velike djelotvornosti omogućuju veći moment sile kod dimenzioniranja ulaznog priključka pa time i manji promjer priključka.

Treba napomenuti da se preporučuje da na duljini ulazne cijevi od 10 njezinih promjera prije separatora ne bi trebalo biti nikakvih ventila ni cijevnih elemenata, da ne dođe do poremećaja protoka i promjene oblika strujanja.

Utjecaj tipa ulaznog raspodjelnika na dimenzije vodoravnog separatora manje je izravan. Upotreba djelotvornog raspodjelnika može smanjiti visinu parnog prostora. Isto tako na visinu parnog prostora može imati utjecaj i potrebna visina za ugradnju demistera. U svakom slučaju visina parnog prostora mora biti dovoljna za ugradnju raspodjelnika plus najmanje 150 mm između HHLL i donjeg ruba raspodjelnika.

\section{Odvajači kapljica}

Odvajači kapljica, demisteri, konačni su stupanj odvajanja u konvencionalnim gravitacijskim separatorima. Povijesno promatrano, kada se govori o odvajačima kapljica ili demisterima, tada su to odvajači u obliku sloja mrežica ili vlakana. Taj se tip odvajača kapljica najčešće upotrebljava, ali sve veću primjenu imaju pločasti odvajači posebno za sustave velikog kapaciteta.

Od svih tipova odvajača kapljica iz plinskog toka, kolizijski odvajači imaju najširu primjenu. Oni imaju dobar odnos između djelotvornosti, radnog područja, pada tlaka i cijene instalirane opreme.

\section{Svojstva odvajača ovise o sljedećem:}

- djelotvornosti uklanjanja kapljica; zahtijevana djelotvornost odvajanja i tolerirana količina preostalih kapljica tekućine u struji plina određena je osjetljivosti procesa nakon separatora na sadržaj kapljevine u plinu

- kapacitet na plin obično se određuje maksimalnom brzinom strujanja plina prije nego odnošenje kapljica tekućine postane preveliko

- kapacitet za kapljevinu je gustoća volumnog toka kapljevine u plinu na ulazu u odvajač koju odvajač može prihvatiti, a da separacija bude zadovoljavajuća.

Ostala svojstva odnose se na moguće smanjenje kapaciteta i otpornost na nečistoće.

Žičana mrežica (slika 9) je najčešće upotrebljavan tip odvajača. Vjerojatno po primjeni nadmašuju sve ostale tipove zajedno. Izrađene su od pletenih (rjeđe tkanih) žičanih mrežica. Svojstva i konstrukcijski parametri dani su u tablici 5 .

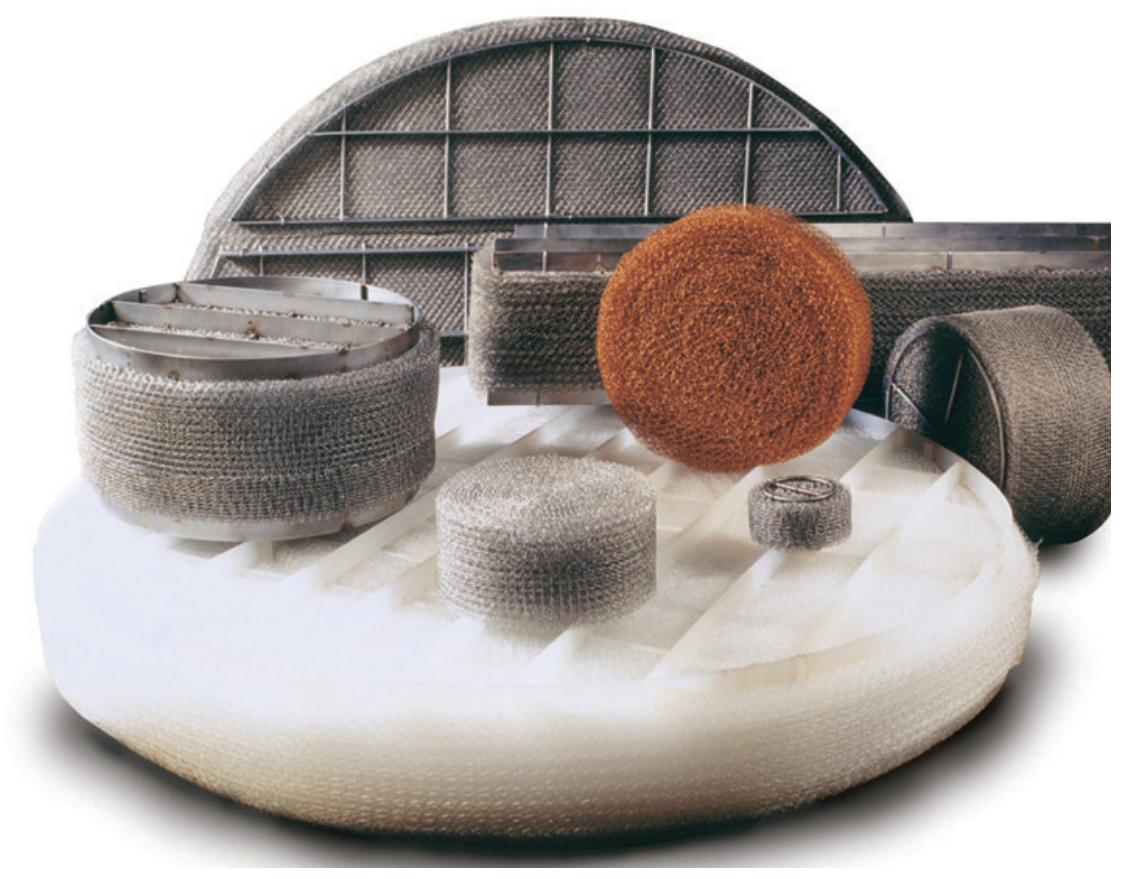

Slika 9 - Odvajači kapljica od žičanih mrežica

Fig. 9 - Wiremesh mist eliminators 
Tablica 5 - Svojstva i konstrukcijski parametri odvajača od žičane mreže ${ }^{9}$ Table 5 - Design and construction parameters of wire mist separators ${ }^{9}$

\begin{tabular}{|c|c|c|c|}
\hline \multirow{2}{*}{$\begin{array}{l}\text { Parametar } \\
\text { Parameter }\end{array}$} & \multicolumn{3}{|c|}{$\begin{array}{l}\text { Tip } \\
\text { Type }\end{array}$} \\
\hline & $\begin{array}{l}\text { standardni } \\
\text { standard }\end{array}$ & $\begin{array}{l}\text { velikog kapaciteta } \\
\text { high capacity }\end{array}$ & $\begin{array}{c}\text { dvostruko pletivo velike } \\
\text { djelotvornosti } \\
\text { high efficiency co-knit mesh }\end{array}$ \\
\hline$\rho / \mathrm{kg} \mathrm{m}^{-3}$ & 145 & 80 & 190 \\
\hline $\begin{array}{l}\text { slobodni volumen } / \% \\
\text { voidage } / \%\end{array}$ & 98,5 & 99,0 & 96,2 \\
\hline $\begin{array}{l}\text { specifična površina } / \mathrm{m}^{2} \mathrm{~m}^{-3} \\
\text { surface area } / \mathrm{m}^{2} \mathrm{~m}^{-3}\end{array}$ & 280 & 150 & $\begin{array}{c}270 \\
3610\end{array}$ \\
\hline $\begin{array}{l}\text { promjer žice } / \mathrm{mm} \\
\text { wire diameter } / \mathrm{mm}\end{array}$ & 0,279 & 0,279 & $\begin{array}{l}0,279 \\
0,0128\end{array}$ \\
\hline$K / m s^{-1}$ & 0,107 & 0,122 & 0,0762 \\
\hline $\begin{array}{l}\text { maks. opterećenje kapljevinom } / \mathrm{m}^{3} \mathrm{~s}^{-1} \mathrm{~m}^{-2} \\
\text { maximal liquid load } / \mathrm{m}^{3} \mathrm{~s}^{-1} \mathrm{~m}^{-2}\end{array}$ & 0,0017 & 0,0033 & 0,0011 \\
\hline
\end{tabular}

Smjer strujanja plina okomito naviše.

Maksimalno opterećenje je opterećenje prije pada kapaciteta. Ako opterećenje kapljevinom prelazi vrijednosti dane u tablici, kapacitet pada $10 \%$ za svakih $0,003 \mathrm{~m}^{3} \mathrm{~s}^{-1} \mathrm{~m}^{-2}$. Podatci su preliminarni. Za točne podatke treba kontaktirati proizvođača.
Gas flow vertical.

Maximal load before capacity deterioration. If liquid load exceeds given values capacity decreases $10 \%$ per $0.003 \mathrm{~m}^{3} \mathrm{~s}^{-1} \mathrm{~m}^{-2}$

Preliminary data. For exact data consult the manufacturer.
Debljina sloja kreće se od 100 do 300 mm. Sloj je postavljen između rešetki nosača. Rešetke trebaju imati dovoljno veliku slobodnu površinu za nesmetan protok plina. Obično se postavljaju tako da je strujanje plina okomito na gore, iako se mogu u nekim posebnim slučajevima postaviti za vodoravno strujanje plina.

Djelotvornost se može odrediti sljedećim postupkom: ${ }^{9}$
Izračuna se Stokesova značajka:

$$
S t k=\frac{\left(\rho_{\mathrm{L}}-\rho_{\mathrm{G}}\right) D_{p}^{2} u_{\mathrm{G}}}{18 \mu_{\mathrm{G}} d_{\mathrm{w}}}
$$

Iz slike 10 očitava se djelotvornost jedne žice pletiva.

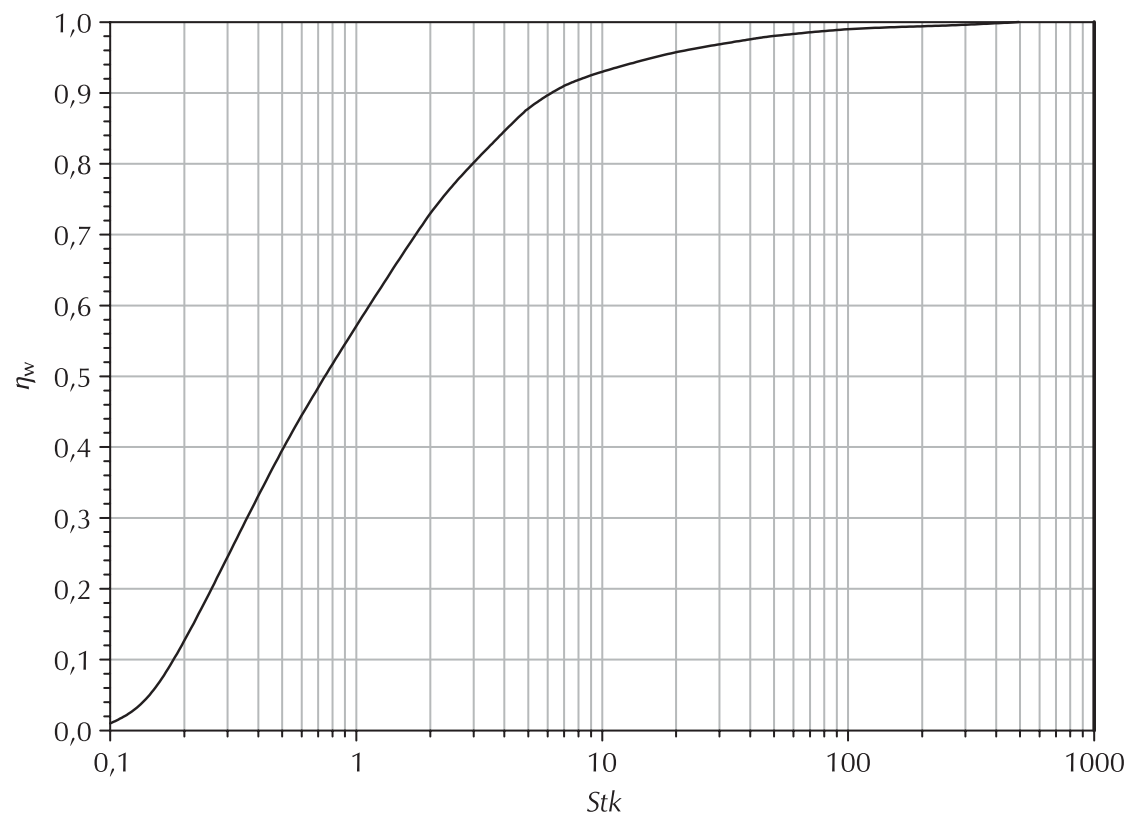

Slika 10 - Djelotvornost odvajanja kapljica iz struje plina ${ }^{9,10}$

Fig. 10 - Separation efficiency of liquid droplets from gas flow ${ }^{9,10}$ 
Aproksimacija krivulje na slici 10 dana je korelacijom:

$$
\eta_{\mathrm{w}}=\frac{0,995 \cdot S t k^{1,00493}-0,105}{0,621+S t k^{1,00493}}
$$

Djelotvornost mrežice se izračuna iz: ${ }^{10}$

$$
\eta_{\mathrm{me}}=1-\exp \left(0,238 A_{s, \mathrm{me}} t_{\mathrm{me}} \eta_{\mathrm{w}}\right)
$$

Pad tlaka kroz žičanu mrežicu sastoji se od pada tlaka kroz suhu mrežicu i pada tlaka kroz vlažnu mrežicu. Shell GSI ${ }^{6}$ preporuča za ukupni pad tlaka sljedeću korelaciju:

$$
\begin{gathered}
\frac{\Delta p}{\mathrm{~Pa}}=200 \cdot \frac{\left(\rho_{\mathrm{L}}-\rho_{\mathrm{G}}\right)}{\mathrm{kg} \mathrm{m} \mathrm{m}^{-3}} \cdot \frac{\lambda^{2}}{\mathrm{~m}^{2} \mathrm{~s}^{-2}} \cdot \frac{t_{\mathrm{me}}}{\mathrm{m}} \\
\frac{\Delta p_{\mathrm{me}}}{\text { stupac kapljevine } \mathrm{u} \mathrm{mm}}=20000 \cdot \frac{\lambda^{2}}{\mathrm{~m}^{2} \mathrm{~s}^{-2}} \cdot \frac{t_{\mathrm{me}}}{\mathrm{m}}
\end{gathered}
$$

$\lambda$ je faktor opterećenja mrežice plinom:

$$
\lambda=q_{\mathrm{vG}} \sqrt{\frac{\rho_{\mathrm{G}}}{\left(\rho_{\mathrm{L}}-\rho_{\mathrm{G}}\right)}}
$$

Pad tlaka kroz suhu mrežicu je 50 \% od tih vrijednosti.

Pločasti odvajači kapljica (slika 11). Odvajač se sastoji od serije paralelnih ploča između kojih prostrujava plin. Površina ploča je "hvatač" kapljica. Najčešći su odvajači od valovitih ploča ili chevron-tip ploča. Konstrukcijske i radne karakteristike dane su u tablici 6.

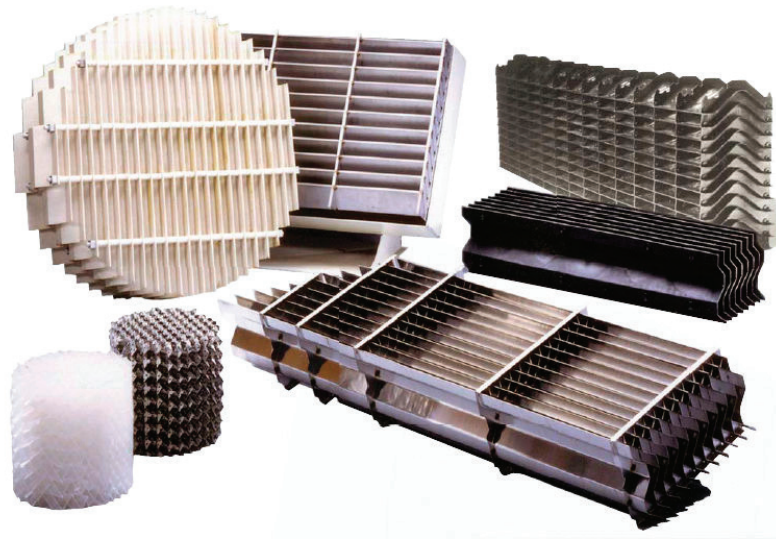

Slika 11 - Ševronski odvajači kapljica Fig. 11 - Chevron type mist eliminator

Djelotvornost se može procijeniti iz: ${ }^{11}$

$$
\eta=1-\exp \left(\frac{-D_{\mathrm{p}}^{2} \rho_{\mathrm{L}} u_{\mathrm{G}} n \Theta}{515,7 \mu_{\mathrm{G}} b \cos ^{2} \Theta}\right)
$$

a pad tlaka iz: 6

$$
\Delta p=K_{\mathrm{v}}\left(\rho_{\mathrm{L}}-\rho_{\mathrm{G}}\right) \lambda^{2}
$$

\begin{tabular}{|c|c|c|c|c|}
\hline \multirow{3}{*}{$\begin{array}{l}\text { Parametar } \\
\text { Parameter } \\
\text { smjer toka plina } \\
\text { gas flow direction }\end{array}$} & \multicolumn{4}{|c|}{$\begin{array}{l}\text { Tip } \\
\text { Type }\end{array}$} \\
\hline & \multicolumn{2}{|c|}{$\begin{array}{l}\text { standardni } \\
\text { simple vane }\end{array}$} & \multicolumn{2}{|c|}{$\begin{array}{l}\text { velikog kapaciteta, s džepovima } \\
\text { high capacity, pocketed }\end{array}$} \\
\hline & $\begin{array}{l}\text { okomit } \\
\text { vertical }\end{array}$ & $\begin{array}{l}\text { vodoravan } \\
\text { horizontal }\end{array}$ & $\begin{array}{l}\text { okomit } \\
\text { vertical }\end{array}$ & $\begin{array}{l}\text { vodoravan } \\
\text { horizontal }\end{array}$ \\
\hline $\begin{array}{l}\text { broj koljena } \\
\text { number of bends }\end{array}$ & $5-8$ & $5-8$ & $5-8$ & $5-8$ \\
\hline $\begin{array}{l}\text { razmak između ploča/mm } \\
\text { vane spacing } / \mathrm{mm}\end{array}$ & $12,5-25,0$ & $12,5-25,0$ & $12,5-25,0$ & $12,5-25,0$ \\
\hline $\begin{array}{l}\text { kut koljena } /^{\circ} \\
\text { bed angle } /^{\circ}\end{array}$ & $30-60$ & $30-60$ & $30-60$ & $30-60$ \\
\hline $\mathrm{K} / \mathrm{m} \mathrm{s}^{-1}$ & 0,152 & 0,198 & $0,25-0,35$ & $0,25-0,35$ \\
\hline $\begin{array}{l}\text { maksimalno opterećenje kapljevinom } / \mathrm{m}^{3} \mathrm{~s}^{-1} \mathrm{~m}^{-2} \\
\text { maximal liquid load } / \mathrm{m}^{3} \mathrm{~s}^{-1} \mathrm{~m}^{-2}\end{array}$ & 0,0014 & 0,0014 & 0,0034 & 0,0034 \\
\hline
\end{tabular}

$K_{v}=15$ za ploče s jednostrukim džepovima

$K_{v}=10$ za ploče $s$ dvostrukim džepovima.

Tablica 6 - Svojstva i konstrukcijski parametri pločastih odvajača ${ }^{9}$

Table 6 - Design and construction parameters of vane mist separators ${ }^{9}$

Najčešći je kut od $45^{\circ}$

Maksimalno opterećenje je opterećenje prije pada kapaciteta. Ako opterećenje kapljevinom prelazi vrijednosti dane u tablici, kapacitet pada $10 \%$ za svakih $0,003 \mathrm{~m}^{3} \mathrm{~s}^{-1} \mathrm{~m}^{-2}$.

Podatci su preliminarni. Za točne podatke treba kontaktirati proizvođača.
Common angle is $45^{\circ}$.

Maximum load is load before capacity deterioration. If liquid load exceeds given values capacity decreases $10 \%$ per $2.4 \mathrm{~m}^{3} \mathrm{~s}^{-1} \mathrm{~m}^{-2}$.

These parameters are approximate only. The manufacturer should be contacted for exact ones. 
Odvajači kapljica sa slojem vlakana. Upotrebljavaju se u posebnim slučajevima kada je njihova primjena bez obzira na pad tlaka i cijenu ekonomski opravdana. To su obično slučajevi kada se trebaju odvojiti kapljice promjera manjeg od 2,0 $\mu \mathrm{m}$. Načinjeni su od vlakana malog promjera, obično manjeg od 0,02 mm. Plin i kapljice tekućine struje kroz sloj vodoravno i istosmjerno. Kako je sloj gustog pakiranja, drenaža gravitacijom unutar sloja je ograničena i najveći dio tekućine kreće se potisnut strujanjem plina i drenira s donje površine. Jedinična površina odvajača od sloja vlakana je 3 - 150 puta veća od jedinične površine odvajača od mrežice $s$ istim slobodnim volumenom. Ovisno o mehaniz- mu odvajanja tipične su brzine plina od 1,0 do $3,0 \mathrm{~m} \mathrm{~s}^{-1}$ za odvajanje kolizijom pa do $0,05 \mathrm{~mm} \mathrm{~s}^{-1}-0,2 \mathrm{~mm} \mathrm{~s}^{-1}$ za odvajanje difuzijom.

Kao i za druge odvajače kapljica, proizvođač daje podatke za kapacitet, pad tlaka i djelotvornost. Primjena im je u procesima gdje se trebaju izdvojiti submikrometarske kapljice tekućine.

Izbor tipa odvajača diktiraju radni uvjeti i ekonomika. Pomoć pri izboru može dati tablica 7 usporedbe svojstava ta tri tipa odvajača kao i prikaz djelotvornosti odvajanja pojedinih tipova odvajača (slika 12).

Tablica 7 - Usporedba svojstava odvajača kapljica

Table 7 - Mist eliminators characteristics

\begin{tabular}{|c|c|c|c|}
\hline \multirow{2}{*}{$\begin{array}{l}\text { Svojstva } \\
\text { Characteristics }\end{array}$} & \multicolumn{3}{|c|}{$\begin{array}{l}\text { Tip } \\
\text { Type }\end{array}$} \\
\hline & $\begin{array}{l}\text { žičana mreža } \\
\text { wire mesh }\end{array}$ & $\begin{array}{l}\text { ploče (chevron tip) } \\
\text { vane (chevron type) }\end{array}$ & $\begin{array}{l}\text { sloj vlakana } \\
\text { fibre pad }\end{array}$ \\
\hline $\begin{array}{l}\text { cijena } \\
\text { price }\end{array}$ & 1 & $2-3$ & 10 \\
\hline $\begin{array}{l}\text { djelotvornost } \\
\text { efficiency }\end{array}$ & $\begin{array}{c}100 \% \text { za kapljice } \\
>3-10 \mu \mathrm{m} \\
100 \% \text { for droplets } \\
>3-10 \mu \mathrm{m}\end{array}$ & $\begin{array}{c}100 \% \text { za kapljice } \\
>10-40 \mu \mathrm{m} \\
100 \% \text { for droplets } \\
>10-40 \mu \mathrm{m}\end{array}$ & $\begin{array}{l}\text { do } 99,9 \% \text { za maglu }<3 \mu \mathrm{m} \\
\text { up to } 99,9 \% \text { for mist }<3 \mu \mathrm{m}\end{array}$ \\
\hline $\begin{array}{l}\text { pad tlaka } \\
\text { pressure drop }\end{array}$ & $<25 \mathrm{~mm} \mathrm{H}_{2} \mathrm{O}$ & $<15 \mathrm{~mm} \mathrm{H}_{2} \mathrm{O}$ & $100-300 \mathrm{~mm} \mathrm{H}_{2} \mathrm{O}$ \\
\hline $\begin{array}{l}\text { kapacitet za plin } \\
\text { gas load capacity }\end{array}$ & 5 & $5-15$ & 1 \\
\hline $\begin{array}{l}\text { kapacitet za kapljevinu } \\
\text { liquid load capacity }\end{array}$ & 5 & 10 & 1 \\
\hline $\begin{array}{l}\text { Čvrste čestice } \\
\text { solids }\end{array}$ & 1 & 3 & $\begin{array}{l}\text { samo topljive čestice } \\
\text { only soluble particles }\end{array}$ \\
\hline
\end{tabular}

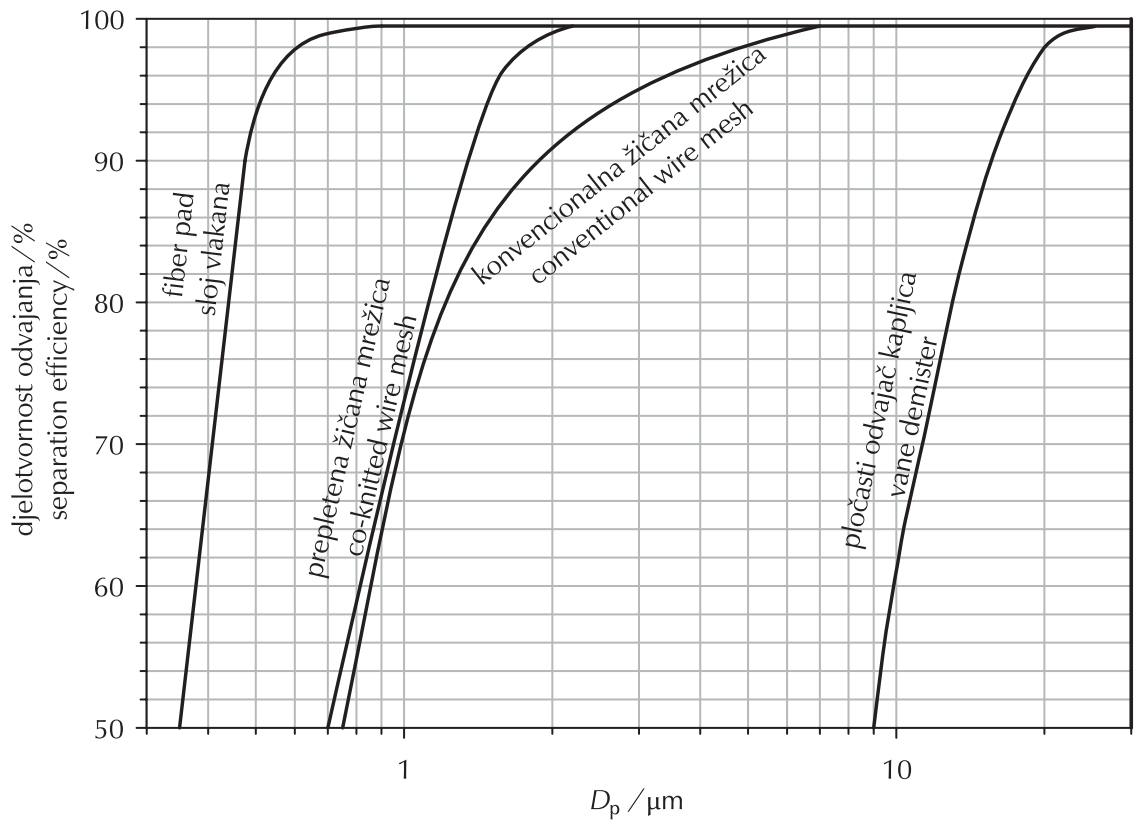

Slika 12 - Djelotvornost odvajanja prema promjeru kapljice za različite tipove odvajača Fig. 12 - Separation efficiency for different types of mist eliminators ${ }^{7}$ 
Djelotvornost: 100 \% uklanjanje kapljica navedenog promjera i većih. To se obično odnosi na sustav zrak/voda na radnim uvjetima okoline $\left(101,3\right.$ bar, $\left.20^{\circ} \mathrm{C}\right)$.

Kapacitet na plin: Pokazuje odnose dimenzija separatora s različitim odvajačima uz iste radne uvjete. Na primjer, zamjenom odvajača iz žičane mreže s pločastim odvajačem tipa chevron separatoru će se povećati kapacitet na plin (protok) i do 3 puta (15/5).

Kapacitet za kapljevinu. Osjetljivost odvajača kapljica na količinu kapljevine na ulazu u odvajač. To na neki način pokazuje kakav tip ulaznog uređaja (distributora) treba postaviti da ne dođe do preopterećenja odvajača kapljevinom, plavljenja i konačno prekomjernog odnošenja kapljica plinom nakon odvajača.

Čvrste čestice. Mogućnost odvajača da radi s nečistoćama u plinu. To se odnosi na plinove u kojima ima čvrstih čestica, voska, asfaltena ili bilo koje druge supstancije koja se može nataložiti na površini odvajača kapljica.

Odvajači od žičane mrežice ili pločasti postavljaju se i vodoravno i okomito. U okomitim separatorima (slika 13a) vodoravno postavljeni odvajači su češći radi smanjenja promjera posude. U vodoravnim separatorima okomiti i vodoravni odvajači su jednako zastupljeni (slika 13b). Ostale orijentacije ( $\mathrm{V}, \mathrm{Z}$ i П) obično se primjenjuju kada se želi povećati kapacitet u istoj posudi.
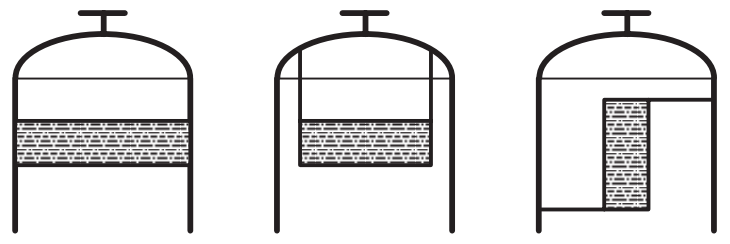

a) okomiti vertical
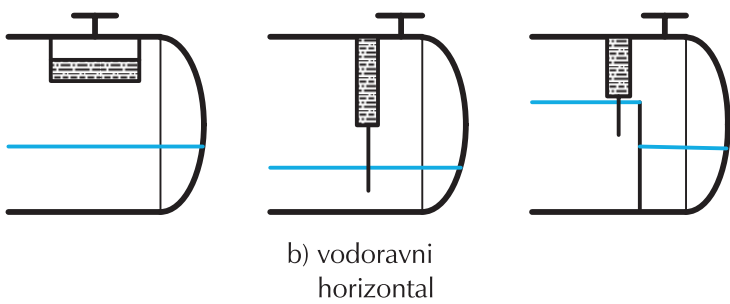

Slika 13 - Neki od načina postavljanja odvajača kapljica Fig. 13 - Mist eliminators arrangements

\section{Izbor tipa separatora}

S obzirom na to da svojstva dvofazne/višefazne smjese i zahtijevani stupanj odvajanja (djelotvornost) mogu varirati u širokom rasponu, treba voditi računa da odabrani tip separatora odgovara zahtjevima procesa. Separator postavljen prije usisa kompresora mora biti veoma djelotvoran, dok je u drugim slučajevima, kada je dovoljno samo "grubo" odvajanje (npr. izmjenjivač topline s kondenzacijom), dovoljna jednostavna KO-posuda.
Separatori mogu biti okomite ili vodoravne posude.

Okomiti separatori odabiru se u sljedećim slučajevima:

- kada je na raspolaganju mala površina za montažu

- kada djelotvornost odvajanja kapljevine ne varira s razinom tekućine u separatoru

- kada je protok kapljevite faze mali u odnosu na protok plinske faze.

Vodoravni separatori odabiru se u slučajevima:

- kada je velik udjel kapljevite faze u dvofaznoj smjesi

- kada je ograničena visina prostora gdje će se montirati separator

- kada se zahtijeva mala brzina kapljevite faze u separatoru (otplinjavanje).

U ovom pregledu raspravljat ćemo o šest tipova separatora.

\section{Okomiti separator bez odvajača kapljica}

Primjena: odvajanje velikih količina plina i relativno male količine kapljevine.

Svojstva: nema ograničenja za smanjenje kapaciteta, djelotvornost odvajanja kapljevine obično > 90 \%. Loša djelotvornost odvajanja kapljica u obliku magle. Mali pad tlaka. Dobri kod sustava s većim nečistoćama.

Preporučena upotreba: separatori kod kojih unutarnjih dijelova treba biti što je moguće manje. Rad s nečistim procesnim tokovima, vosak, pijesak, asfalt.

Ne preporučuje se: za procese gdje se traži djelotvorno odvajanje plina od kapljevine.

Tipična primjena: KO-posude za baklju, brzi isparivači, grubo odvajanje.

\section{Vodoravni separator bez odvajača kapljica}

Primjena: odvajanje velikih količina plina i kapljevine.

Svojstva: separacija smjesa s velikom količinom kapljevine. Nema ograničenja za smanjenje kapaciteta. Pogodni za odvajanje gdje je velika mogućnost povremenih povećanja protoka kapljevine. Mali pad tlaka. Dobri kod sustava s većim nečistoćama.

Preporučena upotreba: separatori kod kojih se traži što je moguće manje unutarnjih dijelova. Rad s nečistim procesnim tokovima, vosak, pijesak, asfalt. Za sustave koji se pjene ili jako viskozne kapljevine.

Ne preporučuje se: za procese gdje se traži djelotvorno odvajanje plina od kapljevine.

Tipična primjena: KO-posude za baklju, brzi isparivači, grubo odvajanje. Odvajanje gdje je velika mogućnost povremenih povećanja protoka kapljevine. 


\section{Okomiti separator s odvajačem kapljica (žičana mrežica)}

Primjena: odvajanje u sustavu gdje su kapljice kapljevine u obliku magle.

Svojstva: Veliki omjer minimalnog i normalnog kapaciteta, 4 : 1. Djelotvornost odvajanja $>98 \%$. Osjetljivi na nečistoće, mali pad tlaka.

Preporučena upotreba: za uklanjanje kapljica iz plina sa srednjim opterećenjem plina kapljicama. Za sustave gdje se očekuje povremeno povećanje protoka. Za usisne skrubere kompresora kod čistih smjesa uz osiguranje da u slučaju oštećenja mrežice neće dijelovi mrežice biti usisani u kompresor.

Ne preporučuje se: primjena kod sustava s voskom, asfaltenima, pijeskom, hidratima. Kod viskoznih kapljevina gdje zahtjev za djelotvornim otplinjavanjem određuje promjer posude.

Tipična primjena: sustavi bez nečistoća, srednji omjer plin/ kapljeviti ugljikovodici, ulazni skruberi za plinovode, separatori malog primjera i niskih radnih tlakova gdje se ne može ekonomski opravdati ugradnja skupljih pločastih odvajača kapljica.

\section{Vodoravni separator s odvajačem kapljica (žičana mrežica)}

Primjena: odvajanje kapljevine iz pojenja s velikim protokom kapljevine.

Svojstva: veliki omjer smanjenja kapaciteta (faktor 4). Dobro prihvaćanje naglih povećanja protoka kapljevine u pojenju. Djelotvornost odvajanja > $98 \%$. Osjetljiv na nečistoće. Mali pad tlaka.

Preporučena primjena: tipična primjena kod velikih protoka kapljevine i malih omjera plin/kapljevina. Primjena u slučajevima kada se očekuje povremeno naglo povećanje protoka kapljevine. Za viskozne kapljevine gdje zahtjev za otplinjavanjem kapljevine određuje promjer posude. Za sustave koji se pjene.

Ne preporučuje se: kod sustava s nečistoćama (vosak, asfalteni, pijesak)

\section{Okomiti separator s pločastim odvajačem kapljica}

Svojstva: djelotvornost odvajanja > $96 \%$. Srednji omjer smanjenja kapaciteta (faktor 3). Prikladan za sustave s manjim nečistoćama. Nije prikladan za tlakove iznad 70 bar. Robusna izvedba. Osjetljiv na nagla povećanja protoka kapljevine.

Preporučena primjena: dvostupanjski separator upotrebljava se kada je parametar protoka $\Phi \geq 0,01$. Iznimno prikladan za sustave s manjim nečistoćama. Upotrebljava se za sustave gdje bi se žičani odvajači mogli začepiti (voskovi, jedinice za rekuperaciju sumpora).

Ne preporučuje se: upotreba kod jako prljavih sustava (teški voskovi, asfalteni, pijesak, hidrati). Viskozne kapljevine gdje otplinjavanje određuje promjer posude. Kada tlak prelazi 70 bar zbog naglog pada djelotvornosti odvajanja i nedovoljnog omjera smanjenja kapaciteta.

\section{Vodoravni separator s pločastim odvajačem kapljica}

Primjena: sustavi s velikim protokom kapljevine.

Svojstva: djelotvornost odvajanja > $96 \%$. Srednji omjer smanjenja kapaciteta (faktor 3). Prikladni za sustave s manjim nečistoćama. Veliki kapacitet svladavanja naglih povećanja protoka. Robusna izvedba.

Ne preporučuje se: kod jako nečistih sustava (teški voskovi, asfalteni, pijesak, hidrati). Za tlakove iznad 70 bar.

Sažeta usporedba svojstava tih šest tipova separatora dana je u tablici 8. 
Tablica 8 - Usporedba i ocjena svojstava tipova separatora: ${ }^{6} \mathrm{~A}$ - vrlo mala, B - mala, C - srednja, D - velika, E - vrlo velika Table 8 - Performance and grade of various types of separators: ${ }^{6} \mathrm{~A}$ - very low, B - low, C - moderate, D - high, E - very high

\begin{tabular}{|c|c|c|c|c|c|c|}
\hline & 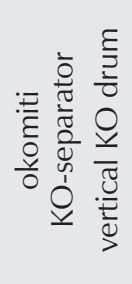 & 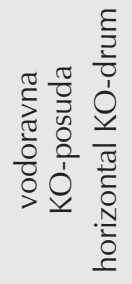 & 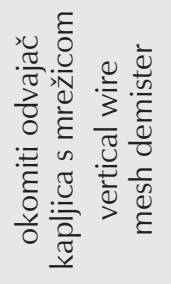 & 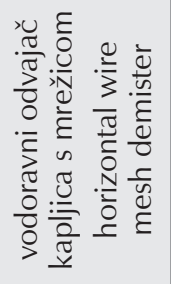 & 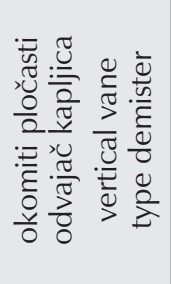 & 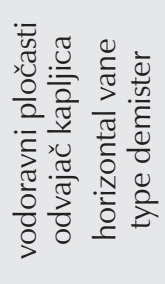 \\
\hline \multicolumn{7}{|l|}{$\begin{array}{l}\text { plin } \\
\text { gas }\end{array}$} \\
\hline$\lambda / \mathrm{m}^{3} \mathrm{~m}^{-2} \mathrm{~s}^{-1}$ & $\mathrm{~B}$ & $\mathrm{~B}$ & $\mathrm{C}$ & $\mathrm{C}$ & $\mathrm{D}$ & $\mathrm{D}$ \\
\hline $\begin{array}{l}\text { smanjenje kapaciteta (maks/min protok) } \\
\text { turndown (max/min flow) }\end{array}$ & $\infty$ & $\infty$ & 2 & 2 & 3 & 3 \\
\hline \multicolumn{7}{|l|}{$\begin{array}{l}\text { djelotvornost odvajanja: } \\
\text { liquid removal efficiency: }\end{array}$} \\
\hline $\begin{array}{l}\text { prosječna djelotvornost } / \% \\
\text { overall efficiency } / \%\end{array}$ & 90 & 90 & $>90$ & $>90$ & $>96$ & $>96$ \\
\hline $\begin{array}{l}\text { u odnosu na maglu } \\
\text { with respect to mist }\end{array}$ & A & A & $\mathrm{E}$ & $\mathrm{E}$ & $\mathrm{C}$ & $\mathrm{C}$ \\
\hline $\begin{array}{l}\text { plavljenje iznad } \lambda_{\max } \\
\text { flooding above } \lambda_{\max }\end{array}$ & - & - & + & + & a) & a) \\
\hline
\end{tabular}

kapacitet s obzirom na kapljevinu:

liquid handling capacity:

\begin{tabular}{|c|c|c|c|c|c|c|}
\hline $\begin{array}{l}\text { kao čepovi } \\
\text { as slugs }\end{array}$ & $\mathrm{D}$ & $E$ & $\mathrm{D}$ & $E$ & $E$ & $\mathrm{D}$ \\
\hline $\begin{array}{l}\text { kao kapljice }\left(Q_{L, \text { max. }}\right) \\
\text { as droplets }\left(Q_{L, \text { max. }}\right)\end{array}$ & $\mathrm{D}$ & $\mathrm{D}$ & $\mathrm{D}$ & $\mathrm{D}$ & $\mathrm{C}$ & $\mathrm{C}$ \\
\hline
\end{tabular}

tolerancija na nečistoće:

fouling tolerance:

\begin{tabular}{|c|c|c|c|c|c|c|}
\hline $\begin{array}{l}\text { pijesak } \\
\text { sand }\end{array}$ & $\mathrm{E}$ & $\mathrm{E}$ & B & B & b) & b) \\
\hline $\begin{array}{l}\text { ljepljive tvari } \\
\text { sticky material }\end{array}$ & $E$ & $\mathrm{E}$ & $A$ & $A$ & b) & b) \\
\hline $\begin{array}{l}\text { pad tlaka } \\
\text { pressure drop }\end{array}$ & $A$ & $A$ & B & B & B & B \\
\hline $\begin{array}{l}\text { a) ako je odvajač dvc } \\
\text { ravne }(+) \\
\text { if double pocket }\end{array}$ & ploc & $\begin{array}{l}\text { b) A ak } \\
\text { ploč } \\
\text { if do } \\
\text { strai }\end{array}$ & et va & $\begin{array}{l}\text { ko je } \\
\text {, if } \mathrm{si}\end{array}$ & edno & es (B); if \\
\hline
\end{tabular}

\section{Popis kratica i simbola \\ List of abbreviations and symbols}
$A_{\mathrm{s}} \quad$ - površina presjeka žičane mrežice okomito na tok plina, $\mathrm{m}^{2}$ - mist separator surface area perpendicular to gas flow, $\mathrm{m}^{2}$
b, $n$ - konstante
- constants
$C_{D}-$ koeficijent trenja
- drag coefficient
$D_{\mathrm{p}} \quad$ - promjer čestice ili kapi, $\mathrm{m}$
- particle/drop diameter, m
$d_{w} \quad$ - promjer žice, $\mathrm{mm}$
- wire diameter, $\mathrm{mm}$
$F_{\mathrm{D}}$ - sila trenja, $\mathrm{N}$
- drag force, $\mathrm{N}$
$F_{\mathrm{g}} \quad$ - gravitacijska sila, $\mathrm{N}$
- force of gravity, $\mathrm{N}$

g - gravitacijsko ubrzanje, $g=9,806 \mathrm{~m} \mathrm{~s}^{-2}$

- gravitational acceleration

K - Souders-Brownov koeficijent, $\mathrm{m} \mathrm{s}^{-1}$

- Souders-Brown coefficient, $\mathrm{m} \mathrm{s}^{-1}$

$K_{\mathrm{rs}} \quad$ - kriterij režima strujanja

- flow patern criterion

$K_{v}$ - faktor u jednadžbi 26 za pad tlaka pločastog odvajača kapljica

- factor in eq. 26 for pressure drop in vane demister

p - tlak, Pa, bar

- pressure, Pa, bar

$\Delta p \quad$ - pad tlaka kroz odvajač, Pa

- pressure drop in demister, Pa

$\Delta p_{\text {me }}$ - pad tlaka kroz odvajač kapljica iz žičane mrežice, Pa

- pressure drop in wiremesh demister, $\mathrm{Pa}$

$Q_{\text {vLh }}$ - volumni protok teže kapljevine, $\mathrm{m}^{3} \mathrm{~h}^{-1}$

- heavy liquid volume flux, $\mathrm{m}^{3} \mathrm{~h}^{-1}$ 


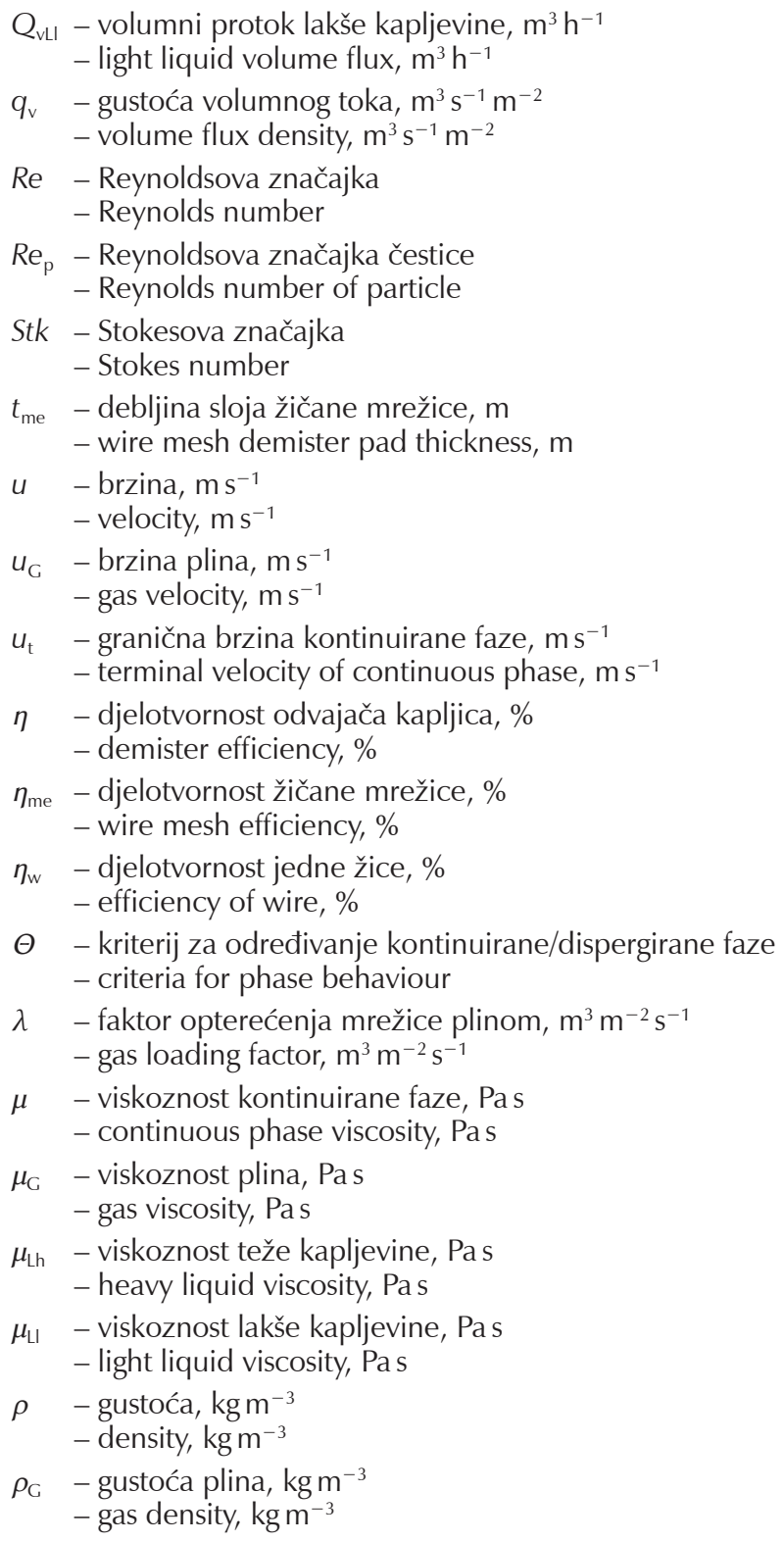
$\rho_{\mathrm{L}} \quad$ - gustoća kapljevine, $\mathrm{kg} \mathrm{m}^{-3}$
- liquid density, $\mathrm{kg} \mathrm{m}^{-3}$
$\rho_{\text {Lh }} \quad$ - gustoća teže kapljevine, $\mathrm{kg} \mathrm{m}^{-3}$
- heavy liquid density, $\mathrm{kg} \mathrm{m}^{-3}$
$\rho_{\mathrm{Ll}} \quad$ - gustoća lakše kapljevine, $\mathrm{kg} \mathrm{m}^{-3}$
- light liquid density, $\mathrm{kg} \mathrm{m}^{-3}$
$\rho_{\mathrm{p}} \quad$ - gustoća čestice ili kapi, $\mathrm{kg} \mathrm{m}^{-3}$
- particle density, $\mathrm{kg} \mathrm{m}^{-3}$

\section{Literatura \\ References}

1. D. W. Green, R. H. Perry (ur.), Perry's Chemical Engineers' Handbook 8. izd., McGraw-Hill, New York, 2008.

2. API Standard 521 Pressure-Relieving and Depressuring Systems.

3. W. L. McCabe, J. C. Smith, Unit Operations of Chemical Engineering, 3. izd., McGraw-Hill, New York, 1976.

4. F. H. Wu, Drum separator design. A new approach, Chem. Eng. 91 (7) (1984) 74.

5. A. H. Selker, C. A. Sleicher, Factors affecting which phase will disperse when immiscible liquids are stirred together, Can. J. Chem. Eng. 43 (1965) 298, doi: http://dx.doi.org/10.1002/ cjce. 5450430606 .

6. Gas/liquid separators - Type selection and design rules, Shell GSI, 2007.

7. S. Rahimi, Three phase separators - Inlet devices, URL: http://chemwork.org/PDF/board/Three\%20phase\%20Separator\%20-\%20Inlet\%20Devices.pdf.

8. S. A. Ziebold, Demystifying mist eliminator selection, Chem. Eng. 107 (5) (2000) 94.

9. M. Bothamley, Gas/Liquids Separators - Part 2, Quantifying Separation Performance, Oil and Gas Facilities 2 (5) (2013) 35.

10. C. L. Carpenter, D. F. Othmer, Entrainment removal by a wire-mesh separator, AIChE J. 1 (4) (1955) 549, doi: http:// dx.doi.org/10.1002/aic.690010428.

11. J. P. Monat, K. J. McNulty, I. S. Michelson, O. V. Hansen, Accurate evaluation of chevron mist eliminators, Chem. Eng. Progr. 82 (1986) 32.

\section{SUMMARY \\ Gravity Vapour/Liquid Separators. Part I. \\ Eduard Beer}

Gravity separators, gas/liquid or gas/liquid/liquid, are common units in gas/oil exploitation and processing, petrochemical, and chemical industries. Due to their simplicity, it is often concluded that they are simple to design. Such an approach can cause serious problems in operation, especially if the separators are in the sensitive part of the process. Wrong sizing of compressor KO drum can cause serious problems or even damage to the compressor cylinder.

This four-part series presents the theoretical background and experience-based data for proper sizing and choice of the most convenient gravity type separator.

The first part presents the theoretical basis, type of internals, feed distributors, mist eliminators, types of separators and their advantages and drawbacks regarding the purposes in the process they are part of.

\section{Keywords}

Gravity separator, gas/liquid separator, gas/liquid/liquid separator, feed distributors, demisters 